\title{
Una relectura del De Principiis a la luz del Comentario al Evangelio de Juan \\ La cuestión de la preexistencia
}

\author{
Patricia Ciner \\ UNIVERSIDAD NACIONAL DE SAN JUAN \\ patriciaciner@yahoo.com.ar
}

Resumen: El objetivo de esta ponencia intentará comparar la doctrina de la preexistencia tal como aparece en el libro II del Comentario al Evangelio de Juan con lo expresado en el De Principiis. Si tenemos presente que tanto el De Principiis como los cinco primeros libros del Comentario al Evangelio de Juan fueron escritos en Alejandría durante el mismo período histórico, creemos que esta tarea será posible. También se deberá considerar como un punto de coincidencia entre ambos textos, la intencionalidad de Orígenes al escribirlos. En efecto, ambos textos están dirigidos a lectores cultos y versados en cuestiones filosóficas y teológicas de alto nivel. Esta comparación nos permitirá entre otras cosas:

1. Determinar si esta doctrina es un postulado fundamental del sistema o una hipótesis construida fundamentalmente contra los gnósticos.

2. Precisar la terminología griega que Orígenes utiliza para explicar la preexistencia.

3. Señalar las semejanzas y diferencias de esta doctrina en ambos textos.

4. Evaluar la frabilidad o no de la traducción de Rufino.

Palabras clave: Preexistencia, Orígenes, De Principiis, Comentario al Evangelio de Juan.

Abstract: The aim of this paper will try to compare the doctrine of preexistence as it appears in the second book of the Commentary on the Gospel of John with that expressed by Origen in De Principiis. If we take into consideration that both De Principiis as the first five books of the Commentary on the Gospel of John were written in Alexandria during the same historical period, this task will be possible. It should also be considered as a point of agreement between the two texts, the intentionality of Origen while writing them. Indeed, both texts are aimed at educated and skilled 
readers in philosophical and theological high-level issues. This comparison allows us, among other things to:

1. Determine whether this doctrine is a central tenet of the system or a hypothesis built primarily against Gnostics.

2. Specify the Greek terminology used by Origen to explain the doctrine of the pre-existence.

3. Indicate the similarities and differences of this doctrine in both texts.

4. Evaluate the reliability or the translation of Rufinus.

Keywords: Pre-existence, Origen, De Principiis, Commentary on the Gospel of John.

Comenzar esta ponencia diciendo que durante siglos el De Principiis ha sido un texto problemático y controvertido, no parecería ningún aporte real al tema. Sin embargo, cuando intentamos indagar el porqué y el para quién este texto ha sido problemático y controvertido, la cuestión toma otra perspectiva. H. Crouzel, por ejemplo, ha sostenido que el De principiis ha sido la causa de los infortunios póstumos de Orígenes, debido a que erróneamente fue comprendido como un primer ensayo de Suma Teológica. En efecto, el gran especialista francés sostiene que:

"Esto no es enteramente exacto. Primeramente, esta obra se inscribe en un conocido género literario filosófico que especula sobre los "principios" que, para Orígenes, son principios en sentido amplio: trinidad, creaturas razonables el mundo, siendo solo el Padre un principio en sentido estricto. Además, él no pretende hablar de manera dogmática, sino que presenta una "teología en ejercicio", es decir en búsqueda, indicando para un problema dos o tres soluciones diferentes, sin sacar él mismo a veces una conclusión, y manifestando también en este libro todas las tensiones que caracterizan su teología, de tal suerte que para sacar de él «un sistema», como a menudo se lo ha hecho, es necesario dejar de lado más de la mitad de lo que se dice" ${ }^{1}$.

Esta postura ya había sido asumida por Pánfilo en el siglo IV, al afirmar en su Apología de Orígenes que:

"Nosotros, sin embargo, constatamos frecuentemente que habla con gran temor de Dios y con toda humildad cuando se excusa por exponer lo que le viene a la mente en el transcurso de discusiones muy

1 H. Crouzel, Orígenes. Un teólogo controvertido (Madrid, 1998), 69-70. 
profundas y de un examen abundante de las Escrituras: en su exposición frecuentemente acostumbra hacer acotaciones y confesar que no está expresando un parecer definitivo o una doctrina establecida, sino que está buscando, en la medida de sus fuerzas que es lo que discute el sentido de las Escrituras y que no pretende haberlo entendido de modo integral ni perfecto" ${ }^{\prime 2}$.

Si bien estamos totalmente de acuerdo en que este estilo "gimnástico"3 de su teología tiene un lugar relevante en el pensamiento de Orígenes, y que además es lo que lo caracteriza como un teólogo libre y valiente, pensamos que en el De Principiis hay un núcleo doctrinario muy firme y preciso ${ }^{4}$. Este núcleo permitiría hablar con toda claridad del "sistema de Orígenes”. Dicho en otros términos, que la teología en búsqueda ${ }^{5}$ no opaca ni disminuye las convicciones profundas de Orígenes. Estas convicciones fueron por otra parte las que le valieron la mayoría de las condenas que su obra sufrió en el siglo VI, y a partir de las cuales su obra fue considerada controvertida y problemática. Esta última afirmación permite identificar el para quién este texto fue "controvertido y problemático". Evidentemente lo fue para una forma de ortodoxia que ya desde la época del obispo Demetrios, concluyó en el Concilio de Constantinopla asfixiando todo el vuelo y la fuerza del cristianismo de Alejandría, que como centro de investigación ${ }^{6}$, tuvo en Orígenes a uno de sus mayores exponentes. Sin embargo, esta posición podría ser fácilmente rebatida al replicar que no hay manera de saber exactamente qué pensaba Orígenes, ya que no contamos con el original griego del De Principiis. Sin embargo y en ayuda de este argumento casi paralizador vienen en auxilio las palabras de Manlio Simonetti, al aconsejar que:

"la desaparición de aquel original impone a la investigación crítica un delicado trabajo de comparación entre la traducción rufiniana -única que nos permite el acceso al texto integro- y el resto de la documentación, en el intento de aproximarse lo más posible al complejo discurso origeniano ${ }^{7 ”}$.

2 PG 17, 543c ss. en H. Crouzel, Orígenes. Un teólogo controvertido, 231-232.

3 A propósito de Orígenes, Atanasio se refiere a este tipo de discurso como lo escrito por ejercicio ( $\gamma v \mu \nu \alpha ́ \zeta \omega v$ Ě $\gamma \rho \alpha \psi \varepsilon)$. Cf. De decretis 27, 1-2.

4 Acerca de las implicancias de este método cf. L. Perrone, "Método" en Adele Castagno (director), Orígenes. Diccionario (Burgos, 2003) 567-575.

5 H. Crouzel, Orígenes. Un teólogo controvertido, 229-237.

6 F. García Bazán, El gnosticismo: esencia, origen y trayectoria (Buenos Aires) 2009.

7 Cf. M. Simonetti, "Principios (los)”, en Orígenes. Diccionario, 744-752. 
Y al concluir su hermoso artículo, afirma: "Más bien, el intérprete deberá recuperar (más allá de la influencia de los "intermediarios", sean admiradores o detractores), la problemática voz del alejandrino"8.

En ese sentido, esta ponencia intentará escuchar y respetar la voz del gran Orígenes, comparando la doctrina de la preexistencia tal como aparece en el libro II del Comentario al Evangelio de Juan con lo expresado en el De Principiis. Si tenemos presente que tanto el De Principiis como los cinco primeros libros del Comentario al Evangelio de Juan fueron escritos en Alejandría durante el mismo período histórico, creemos que esta tarea será posible. También se deberá considerar como un punto de coincidencia entre ambos textos, la intencionalidad de Orígenes al escribirlos. En efecto, ambos textos están dirigidos a lectores cultos y versados en cuestiones filosóficas y teológicas de alto nivel. En el caso específico del Comentario hay que recordar que esta obra fue posible gracias a la ayuda que le proporcionara Ambrosio9, un valentiniano al que el maestro alejandrino había convertido. Este último dato nos muestra claramente la intención profundamente antignóstica de Orígenes, reflejada en sus continuas polémicas con el valentiniano Heracleón. En el caso del De Principiis un tipo de auditorio selecto y conocedor de las problemáticas filosóficas de la época referidas a temas como la providencia, la materia, el cosmos, etc, al que se dirige continuamente cuando escribe ${ }^{10}$.

Esta comparación nos permitirá entre otras cosas:

8 M. Simonetti. "Principios (los)", 752.

9 Esta intencionalidad se halla claramente expuesta en In Joh. Com., V, 8: «Ahora que so pretexto de conocimiento (gnosis), los herejes se sublevan contra la santa Iglesia de Cristo y publican tratados abarcando multitud de libros, que prometen una explicación de los escritos evangélicos y apostólicos, si nosotros guardamos silencio y no les oponemos la doctrina verdadera y salvífica, se tornarán dueños y señores de las almas ávidas que, por falta de un alimento saludable, en su afán se comerán esos alimentos prohibidos, verdaderamente impuros y abominables. Por eso, me parece necesario que si alguien puede defender sin falsificarlo el pensamiento de la Iglesia, se levante para oponer a las invenciones de los herejes la sublimidad de la predicación evangélica, toda ella plena de la armonía de las doctrinas comunes al Testamento llamado antiguo y al del que es llamado nuevo. Tú mismo (Ambrosio), por falta de defensores del bien y porque, en tu amor por Jesús, no te contentabas con una fe irreflexiva en doctrinas de las que luego te apartaste, juzgándole como conviene, pues habías sacado partido de la inteligencia que te había sido dada».

10 Cf. Princ., I, 5, 4; II, 4, 3; II, 6, 1, etc. 
1. Determinar si esta doctrina es un postulado fundamental del sistema o una hipótesis construida fundamentalmente contra los gnósticos.

2. Precisar la terminología griega que Orígenes utiliza para explicar la preexistencia.

3. Señalar las semejanzas y diferencias de esta doctrina en ambos textos.

4. Evaluar la fiabilidad o no de la traducción de Rufino

\section{LAS CONDENAS A LA DOCTRINA DE LA PREEXISTENCIA}

Brevemente y antes de adentrarnos en la comparación misma, citaremos los argumentos sostenidos en las condenas que la doctrina de la preexistencia sufrió durante el siglo VI, ya que esto permitirá darle otra perspectiva a nuestro análisis. Dos documentos fundamentales resumen la posición teológica de ese período de la historia del cristianismo: los diez anatemas que forman parte del edicto de Justiniano en el 543 y los quince anatemas que el mismo emperador envía a los participantes del concilio del $553^{11}$. En esta ocasión mencionaremos los fragmentos directamente relacionados con la preexistencia, ya que se encuentran diferencias que nos pueden permitir advertir las razones por las cuáles está teoría provocó tanto escándalo. En efecto, en el primer documento se afirmaba que:

"Si alguno dice o sostiene que las almas de los hombres preexistieron, es decir que ellas eran antiguamente intelectos y potencias santas, pero que luego se habrían hartado de la divina contemplación y se volvieron hacia lo peor y que por esta razón se han enfriado del amor de Dios y a causa de esto han sido llamadas almas y han sido enviadas en vista del castigo a los cuerpos, ¡que sea anatema!"

El documento del año 553, ampliando más la cuestión sostenía en los anatemas I, II que:

1. "Si alguno sostiene la fabulosa preexistencia de las almas y la monstruosa apocatástasis que la sigue, ¡que sea anatema!

2. Si alguno dice que el conjunto de todos los seres razonables eran intelectos incorpóreos e inmateriales, sin ningún número ni nombre, de suerte que ellos formaban todos una hénada por la identidad de

11 Cf. A. Guillaumont, Les 'Kephalaia Gnostica' D'Evagre Le Pontique. Et L'historie de L'origénisme chez les grecs et chez les syriens (Paris, 1962) 140-147. 
esencia, de potencia y de energía y por la unión al Dios Verbo y de su conocimiento; que ellos habiéndose hartado de la contemplación divina, se inclinaron hacia lo peor, cada una en proporción de su inclinación hacia él, tomando cuerpos más sutiles o más espesos y han recibido un nombre, teniendo en cuenta que las potencias de lo alto tienen diferencias de nombres como también de cuerpos y que de ellos han devenido y han tomado nombre: los unos querubines, los otros serafines, los otros principados, potencias, dominaciones, tronos, ángeles y todos los órdenes celestes que existen, ¡que sea anatema!".

Quizás ante la lectura de estos textos, podríamos preguntarnos qué era lo que hacía tan peligrosa y controvertida la doctrina origeniana de la preexistencia. Para responder a esta pregunta, nada mejor que escuchar la palabra del mismo Orígenes, buscando allí las razones que lo llevaron a sostenerla con tanta decisión a lo largo de su inmensa producción teológica.

3. La doctrina DE LA PREEXISTENCIA COMO POSTULADO FUNDAMENTAL DE la Teología de Orígenes

La doctrina de la preexistencia es sin duda uno de los signos distintivos de la teología origeniana. Sin embargo su verdadero significado no es fácil de determinar, debido a la pérdida de textos esenciales a esta cuestión, como por ejemplo el Comentario al Génesis ${ }^{12}$, así como también por las múltiples controversias que siempre suscitó a lo largo de la historia del cristianismo ${ }^{13}$. En esta ocasión, y tal como lo anticipamos, nos propondremos analizar fundamentalmente un fragmento del texto griego del libro II del Comentario al Evangelio de Juan, en donde Orígenes profundiza en la misión de Juan Bautista, centrando el análisis en la relación existente entre la anterioridad de su alma con respecto al cuerpo. Creemos que esta relación también permitirá obtener interesantes conclusiones acerca de la doctrina de la preexistencia referida a las

12 Cf. M. I. Danieli, "Génesis (escritos exegéticos sobre)”, en Orígenes. Diccionario, 364-369.

13 Cf. E. Norelli, "Orígenes (vida y obras)"; E. Prinzivalli, "Origenismo (en Oriente, siglos III-IV)"; P. Bettiolo, "Origenismo (en Oriente, siglos V-VI)”; B. Studer, "Origenismo (en Occidente, siglos IV, VI)" y G. Lettieri, "Origenismo (en Occidente, siglos VII-XVIII)”, en Orígenes. Diccionario, 617-698. 
almas en general. El análisis de este fragmento se hará en vista de todo el contenido de los Libros I y II del Comentario, buscando siempre la conexión con el De Principiis.

El texto elegido se inicia con la cita de Jn 1, 6 en donde se afirma que: "hubo un hombre enviado por Dios, su nombre era Juan"14. Como lo ha afirmado acertadamente Giulia Sfameni Gasparro:

"[...] la historia del Bautista es para Orígenes la prueba de la anterioridad del alma respecto al cuerpo y, por tanto, de la propia teoría de la preexistencia. A la vez, la preexistencia explica el porqué de la presencia de cada criatura en el mundo actual" 15 .

La fuerza de la exégesis origeniana se centra en la polisemia de significados y de perspectivas del verbo ả $\pi$ o $\tau \hat{\lambda} \lambda \omega$ que básicamente significa enviar ${ }^{16}$. No deja de admirar a los lectores contemporáneos la coherencia interna de la argumentación presentada por Orígenes, la cual hace de este texto una de las mejores piezas literarias y teológicas de su obra. Creemos que la potencia de su genio se muestra con tanta claridad, porque la preexistencia es asumida no como una hipótesis a probar

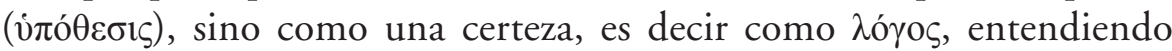
este término como afirmación. Y en ese sentido, y sin ánimo de desmerecer la defensa permanente que hizo $\mathrm{H}$. Crouzel de Orígenes, es necesario corregir las palabras del estudioso francés que tanto éxito tuvieron en el ámbito académico:

"Esta teoría de la preexistencia, incluida en ella la de la humanidad de Cristo, es para Orígenes una hipótesis conforme a la línea constante de su teología cuando no se apoya directamente en la Escritura, pero una hipótesis favorita en base a la cual piensa constantemente aun cuando no la mencione explícitamente" ${ }^{17}$.

Justamente lo que permite advertir el texto griego de Orígenes es que la preexistencia supera ampliamente la categoría de hipótesis y se evidencia como una certeza sin la cual todo su sistema se derrumbaría. Este convencimiento se vería reflejado, como tan acertadamente lo ha

14 Cf. P. Ciner, "Santidad y Preexistencia en la teología de Orígenes" en Epimeleia, 35/36 (2009) 75-90.

15 G. Sfameni Gasparro, "Preexistencia” en Orígenes. Diccionario, 736-744.

16 In Joh. Com., II, 175-192.

17 H. Crouzel, Orígenes. Un teólogo controvertido, 289. 
advertido el investigador J. O'Leary ${ }^{18}$, en el uso de verbos en imperativo y en futuro, lo cual muestra que Orígenes está enseñando cómo debe ser entendido el texto bíblico. Si tenemos en cuenta que Orígenes siempre se distinguió por su humildad y sinceridad en reconocer sus limitaciones cuando una cuestión teológica lo sobrepasaba, dando lugar a su famosa "teología en búsqueda", llama la atención su total convencimiento con respecto a la cuestión de la preexistencia. A fin de no romper la estructura del fragmento elegido, haremos la comparación con el De Principiis al final de su estudio.

Orígenes comienza su análisis del fragmento del libro II del Comentario al Evangelio de Juan, mostrando que solo un oyente bien preparado

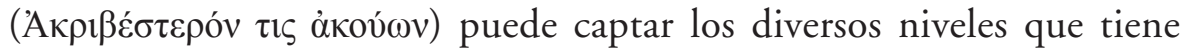
el término $\dot{\alpha} \pi \varepsilon \sigma \tau \alpha \lambda \mu \varepsilon ́ v o \zeta$. Esta advertencia es una continuación de lo explicitado por Orígenes al comienzo del Libro I del Comentario con respecto a que el Evangelio de Juan, debe ser considerado como el texto del Nuevo testamento en el que se esconden las verdades más profundas y que solo está reservado a la lectura de aquellos que se encuentran en condiciones espirituales para comprenderlo. En sus propias palabras:

"Por tanto es necesario osar decir que los Evangelios son las primicias de la Escritura, y el Evangelio de Juan primicias del Evangelio. Nadie puede comprenderlo si no ha reposado sobre el pecho de Jesús y si no ha recibido de Jesús a María por madre. Y para ser otro Juan, es necesario convertirse en Juan, ser llamado por Jesús como siendo Jesús mismo ${ }^{19}$.

Los perfectos (oi $\tau \dot{\lambda} \lambda \varepsilon ı 1$ ), los verdaderos discípulos del Lovgo", constituyen entonces para Orígenes la categoría antropológica por excelencia para adentrarse en la cuestión misma del envío de Juan ${ }^{20}$. Aclarados los

18 J. O'Leary, La philsophie chez Origéne (Paris, 2010).

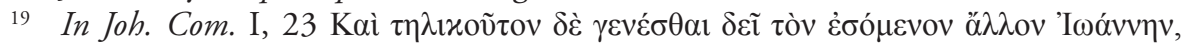

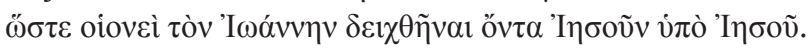

20 Y aquí cobra toda su fuerza el tema de la iniciación de los perfectos ( $\sigma \tau o \imath \chi \varepsilon i ́ \omega \sigma ı \varsigma)$ en los misterios de la Sabiduría, por intermediación del Logos. Los perfectos para Orígenes, no constituyen una categoría privilegiada y heterogénea, a la manera de los Pneumáticos de los Valentinianos, sino la culminación en la participación del $\Lambda$ óyos por parte de las criaturas racionales. Sin embargo, la diversa participación del $\Lambda$ ó $o \varsigma$ no obedece únicamente al progreso ininterrumpido del logos o razón, de modo que sea posible ampliar con las propias fuerzas racionales la capacidad de recibir la forma divina del $\Lambda$ ó ${ }_{0}$. Es necesaria la gracia para adentrarse y descubrir los "tesoros divinos". Los fieles creyentes, en virtud del carisma de la fe, han sido 
destinatarios de esta explicación, Orígenes comienza a clarificar la significación del término enviado. Su primera característica es su relacionalidad, ya que permite vincular "el de donde" ( $\pi$ ó $\theta \varepsilon v)$ alguien ha sido enviado con "el a donde" ( $\pi$ oṽ) ha sido enviado, lo cual da cuenta de su dinamicidad intrínseca. Luego explica que en un sentido históricotemporal "el a donde" ha sido enviado Juan parece obvio: es a Israel y a aquellos que han querido escucharlo cuando él permanecía en el desierto de Judea y bautizaba cerca del Jordán. Esta explicación se resume en una

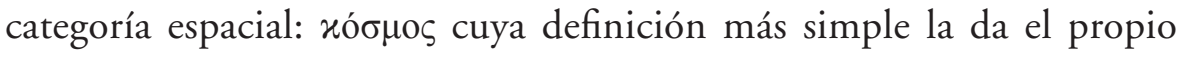
Orígenes:

"es en este mundo, entendiendo por mundo la superficie de la tierra

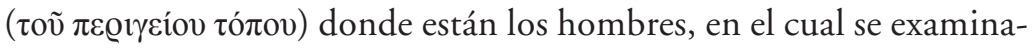
rá como explicar el "de donde" (él ha partido) ${ }^{21}$ ".

Sin embargo nuevamente arremete buscando un nuevo nivel de sig-

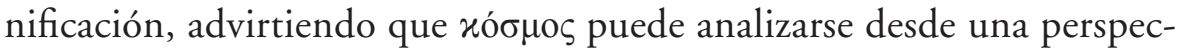
tiva más profunda. Para tal fin recurre al Génesis, lo cual muestra a las claras su intención explícita de señalar la continuidad y armonía entre los dos Testamentos en contra de los marcionitas, que objetaban esta continuidad $^{22}$. Y así afirma que:

"En el curso de un examen más atento de palabra a palabra, se hará posiblemente manifiesto que de la misma manera está escrito de Adam: "El Señor Dios lo expulsó del paraíso de las delicias, para cultivar la tierra del que él había sido sacado", de la misma manera Juan fue enviado sea del cielo, sea del paraíso, sea de no importa qué otro lugar diferente de este lugar terrestre y fue enviado para "dar testimonio a la luz"23.

capacitados para descubrir, no solo las razones seminales sembradas por doquier en el cosmos, sino las huellas del $\Lambda o ́ \gamma o \zeta$ dejadas por su humanidad, llegando así, hasta el Logos-encarnado y poniendo en El todas sus esperanzas. Los perfectos en cambio, en virtud de su unción con el Espíritu de filiedad adoptiva, tienen capa-

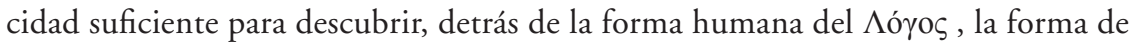
Dios primigenia. Perfecto es entonces el que participa de las غ̇ंívoı $\alpha$ superiores de Cristo, de la cual la principal es la Sabiduría.

21 In Joh. Com., II, 175.

22 La continuidad y armonía entre los dos Testamentos también es un eje central del De Principiis.

23 In Joh. Com., II, 177. 
Esta explicación permite a Orígenes enfrentar, como él mismo lo dice, las críticas del adversario que solo aceptaría una explicación superficial del asunto, entendiendo que el $x o ́ \sigma \mu o \varsigma$ se limita a la superficie te-

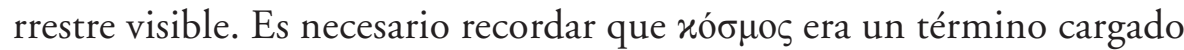
con una larga tradición cosmológica y teológica que Orígenes conocía perfectamente y ante la cual toma partido. Según el contexto Orígenes dará a este término una perspectiva diferente, no porque su cosmología carezca de precisión, sino porque justamente advierte que este término puede tener una polisemia de significados a partir del texto de la Escritura, que lo obliga a discernir las coordenadas filosóficas y teológicas en que se sustentan ${ }^{24}$. Aclarado este modo de proceder del maestro alejandrino y volviendo a las dos definiciones que ha dado acerca de xóøuos en Comentario al Evangelio de Juan, vemos que la primera está muy próxima a las coordenadas estoicas ${ }^{25}$. En efecto, se puede observar claramente en ella la terminología de Crisipo. En la segunda hay una intención explícita de rebatir la tesis del gnóstico Heracleón, acerca de que el texto evangélico "Todo llegó a ser por él” ${ }^{26}$ se limita exclusivamente al xó $\mu$ o $\varsigma$ material y a todos los elementos materiales -por ende corruptibles- que hay en él ${ }^{27}$. Orígenes muy por el contrario buscará mostrar que el $x o ́ \sigma \mu o \varsigma$ como expresión del $\Lambda$ ó ${ }^{\prime} \varsigma$ incluye tanto el plano visible como el invisible, lo cual explicaría el "de donde" y "al donde" Juan ha sido enviado. Esta doctrina será totalmente explicitada en Libro XIX del mismo Comentario en donde afirma que:

"Además del mundo visible y sensible que consta de cielo y tierra, o de cielos y tierra, hay otro mundo en el que viven los seres que no se ven y todo ello es mundo visible, mundo que no ve y mundo inteligible. Con su vista y hermosura gozarán los limpios de corazón, preparados mediante su contemplación para entrar a contemplar a Dios, como Dios puede ser contemplado ${ }^{28}$ ".

Esta argumentación permite a criterio de Orígenes, desarmar al adversario que básicamente asume dos modalidades: el cristiano simple que solo encuentra en la palabra "enviado" un cambio de lugar en el plano de lo visible y el gnóstico que pretende afirmar que la actividad del $\Lambda$ ó

\footnotetext{
24 A. Castagno "Cosmos" en Orígenes. Diccionario, 178-190.

25 Cf. Diog. Laer., 7, 137-138; E. Corsini en Commento al Vangelo di Giovanni, 140.

26 Jn 1,3

27 Cf. A. Orbe, En los Albores de la Exegesis Iohannea (Roma, 1955) 11-83.

28 In Joh. Com., XIX, 22.
} 
y de la $\Sigma o \varphi \alpha^{29}$, no tendrían incidencia en el mundo sujeto al tiempo y al espacio. Para Orígenes por el contrario, ambas ė $\pi$ ívoral sintetizan la esencia misma del Hijo, pero no como entidades diferentes, sino como momentos ontológicos del Hijo. Orígenes es plenamente consciente que de su definición de Sabiduría, dependerá su cercanía o lejanía de la filosofía griega y helenística, del pensamiento gnóstico y por supuesto de toda la literatura sapiencial hebrea. Sin duda alguna, Orígenes se alista dentro de esta última tradición de ideas, mostrando como la Sabiduría es la غ̇ंívorar más antigua de todas y le cabe por lo tanto ser identificada con la noción de ả@ $\chi \eta^{30}$. La Sabiduría por ser la غ̇лívotal primera es la que tiene más "dignidad ontológica" y no es posible advertir en ella ningún tipo de caída pleromática, como lo sostendrá el pensamiento gnóstico en general. Justamente el maestro alejandrino quiere mostrar que la causa del mal en el cosmos no está en la materia ${ }^{31}$, que según los gnósticos sería producto de la desobediencia del eón sabiduría, sino del libre arbitrio de las criaturas espirituales, que por su propia decisión se alejaron de Dios ${ }^{32}$. Esta forma de interpretación de la literatura sapiencial, tiene por objetivo principal mostrar que tanto el cosmos sensible, como el inteligible fueron organizados según las líneas directrices de la sabiduría y en ese sentido estas dos dimensiones de lo real, son bellas. Cabe aclarar que esta misma cristología es la que encontramos a lo largo de todo el De Principiis ${ }^{33}$. Esta idea se reafirma en el siguiente fragmento del Comentario al Evangelio de Juan:

"La Sabiduría dice en efecto en Salomón: «El Señor me ha formado como el principio de sus caminos en vista de sus obras", de manera que «el Logos existía en el principio» (es decir) en la Sabiduría: pues la sabiduría es considerada en la formación del pensamiento que ha

29 Cf. P. Ciner, "El Logos como maestro interior" en IV Jornadas de Filosofía Medieval (Bs. As. 2009).

30 P. Ciner, Implicancias Teológicas y Misticas de la noción de Sabiduría en Orígenes (Mendoza, 2010). Publicación del Centro de Estudios de Filosofía y Letras, Año III, No 6.

31 Cf. Textos Gnósticos. Biblioteca de Nag Hammadi I. Tratados filosóficos y cosmológicos, a cargo de A. Piñero, J. Montserrat Torrens y F. García Bazán (Madrid, 1997).

32 P. Ciner, "La génesis del mal en Orígenes", en Cristianismo y helenismo en la filosofía tardo-antigua y medieval, publicado por la Facultad de Humanidades y Artes de la Universidad Nacional de Rosario y el Instituto Superior Don Bosco (Profesorado de Filosofía), Ediciones Paideia (Rosario, 2009), 45-52.

33 Princ., I, 2. 
organizado a todas las cosas y en la de sus nociones, y el Logos en la comunicación de las consideraciones de este pensamiento a los seres dotados de razón”. Mira si nosotros no podemos interpretar el texto: «En el principio existía el Logos» según el sentido espiritual: todas las cosas son creadas según la sabiduría de acuerdo a líneas directrices de un plan cuyos elementos (nociones) están en el Logos ${ }^{34 ”}$.

Este breve excursus sobre las implicancias de las nociones de Sabiduría y Logos en la cosmología origenista, nos permite continuar con el análisis de la preexistencia desde una visión más completa, ya que es posible ad-

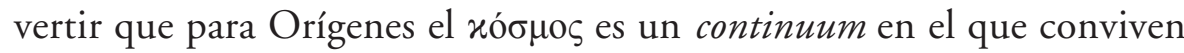
diferentes dimensiones de lo real que están absolutamente relacionadas (material, etérea, inteligible $)^{35}$. En efecto, en el fragmento que analizaremos a continuación el maestro alejandrino profundiza esta perspectiva de una manera sorprendente:

“Tales serían entonces las objeciones a nuestra primera explicación; pero he aquí la solución que se puede proponer para obtener la adhesión a una significación más profunda de Juan: lo que continúa del texto dice: "Aquel que vino como testigo, para dar testimonio a la luz». Pero si él ha venido ha venido de alguna parte. Si alguien tiene dificultad en admitirlo es necesario citarle las palabras de Juan que en la continuación del texto, dice haber visto al Espíritu Santo descender como una paloma sobre el Salvador. Efectivamente él dice: «Aquel que me ha enviado a bautizar en el agua me ha dicho: aquel sobre el que tú verás al espíritu descender y permanecer, es él quien bautiza en el espíritu santo y en el fuego». ¿Cuándo entonces lo envío dándole estas instrucciones? A esta pregunta se puede responder con verosimilitud que enviándolo a bautizar por primera vez, aquel que habla le ha dicho estas palabras. Un argumento aún más sorprendente para que Juan haya venido de otra parte a asumir un cuerpo

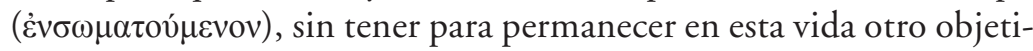
vo más que el testimonio de dar a la luz, es el hecho que él fue plenificado del Espíritu Santo desde el seno de su madre, afirmado por Gabriel anunciando a Zacarías la buena nueva del nacimiento de Juan y a María la de la venida de nuestro Salvador entre los hombres, y estas palabras (de Elizabeth) «He ahí que cuando el sonido de tu saludo llegó a mis oídos, mi hijo se ha estremecido de alegría en mi seno». Si uno se preocupa por no hacer nada con injusticia, nada por azahar

34 In Joh. Com. I, XIX, 111.

35 Cf. P. Tzamalikos, Origen: Cosmology and Ontology of Time (Leiden, 2006). 
o por capricho, se está obligado a admitir que el alma de Juan es más antigua que su cuerpo, que estaba como substrato antes que él (xaì $\pi \varrho o ́ \tau \varepsilon \varrho o v ~ v ́ \varphi \varepsilon \sigma \tau \tilde{\omega} \sigma \alpha v)$ y que ha sido enviada para dar testimonio a la luz. Por otra parte no hay que despreciar esta palabra: «Es Elías quien debe volver». Si la teoría general sobre el alma-ella no está sembrada con el cuerpo, sino que estando antes que él, está ligada a la carne y a la sangre por motivos diversos, (si esta teoría) prevalece, la expresión "enviado de Dios» aplicada a Juan, no parecerá más excepcional36".

En este fragmento tenemos claramente explicitado dos cuestiones: la preexistencia del alma de Juan con respecto a su cuerpo y la posibilidad que tienen los santos de ser instruidos directamente por Dios, antes de la entrada en el cuerpo físico. No es posible hacer en este trabajo un examen detallado de las razones que llevaron a Orígenes a sostener la doctrina de la preexistencia. Sin embargo y a modo de apretada síntesis podríamos decir que, si bien la tradición platónica influyó mucho en su sistema, las razones que determinaron a Orígenes a postularla, son básicamente tres ${ }^{37}$. En primer lugar la certeza de que el texto bíblico afirma de una u otra forma la preexistencia, en segundo lugar la constatación empírica de la desigualdad de las condiciones humanas al nacer y en tercer lugar las controversias con los valentinianos y los marcionitas. Si bien en este texto, no aparece el término comúnmente traducido por preexistencia, es evidente que este fragmento contiene una de las mejores descripciones de la anterioridad del alma con respecto al cuerpo. En trabajos anteriores ${ }^{38}$, hemos señalado la necesidad de clarificar la palabra preexistencia (en latín praexistentia) ya que pensamos que no da cuenta de la intención de Orígenes, de explicar el origen mismo del ser humano en general y del alma en particular. El término mismo preexistencia, tendría la connotación de algo previo a la dimensión de lo real, a la verdadera existencia, lo cual es inaceptable para Orígenes. Y justamente el planteo de Orígenes está dirigido a mostrar que esta eternidad del principio convive con la dimensión material que está sujeta al tiempo

36 In Joh. Com., II, 179-192

37 Cf. M. J. Edwards, Origen against Plato (London, 2002).

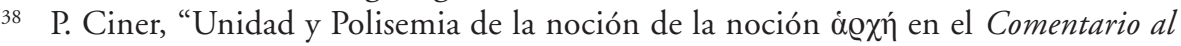
Evangelio de Juan de Orígenes", Teología y Vida, 52 (2011) 93-104; P. Ciner, "La preexistencia en la teología de Orígenes: historia de una noción controvertida”, en Controversias Filosóficas, Cientificas y Teológicas en el Pensamiento Tardo-Antiguo y Medieval (Rosario 2011) 37-47. 
y al espacio. En otros términos: que las criaturas espirituales $\left(v^{2} i^{39}\right)$ no pierden jamás el contacto directo con lo divino, independientemente del estado transitorio que asuman al hacer uso de su libertad (ángel, hombre o demonio). Esto implica que "el pasaje de regreso al seno divino" está inscripto en la naturaleza profunda del alma humana y que en esta especie de "código genético espiritual" se tiene la posibilidad de participar de la Sabiduría divina, que es lo da sentido a la vida humana. Un análisis detallado de los términos que Orígenes utiliza para designar la preexistencia, permitirá advertir el uso de las siguientes palabras que han sido traducidas por preexistencia, pero que deben ser precisadas en cada contexto: cuando se refiere al Logos que preexiste en cada alma,

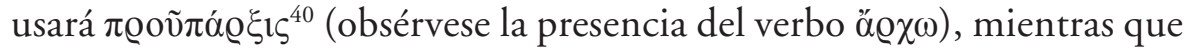
como en este fragmento explique la antigüedad del alma con respecto al cuerpo, empleará v́ $\varphi \varepsilon \sigma \tau \tilde{\omega} \sigma \alpha v^{41}$. En efecto, v́ $\varphi \varepsilon \sigma \tau \tilde{\omega} \sigma \alpha \nu$ debería ser traducido como "estar debajo como soporte", lo que mostraría la existencia de una realidad que permanece idéntica a lo largo de la eternidad y que permitiría afirmar que el Bautista existió antes de su cuerpo. Estas tres razones se unen en la concepción de un Dios concebido esencialmente como justo y amoroso y en la libertad de las criaturas espirituales que son las que deciden el ritmo en el progreso hacia su único objetivo que es la unión total con lo divino. La preexistencia sería entonces una condición inherente a todas las almas, no solamente a la de los santos o seres puros.

En cuanto a la posibilidad de recibir una instrucción o un mandato de Dios mismo, esto sí sería condición de los santos. Y así lo explica Orígenes:

"Veamos si nosotros podemos resolver así la cuestión: de la misma manera que todo hombre es en el sentido más simple hombre de Dios, porque él es creado por Dios, y que (sin embargo) todo hombre no es llamado de Dios, sino simplemente aquel que está consagrado a Dios -como Elías y aquellos que en las Escrituras, son desig-

39 Cf. H. Crouzel, Orígenes. Un teólogo controvertido, 289.

40 Cf. In Joh. Com., II, XVIII, 129: "Pues es necesario que el Logos que purifica al alma, preexista ( $\pi \varrho 0 \tilde{\pi} \alpha$ $\varrho \xi 1 \alpha$ ) en el alma para que luego de él y su intervención purificadora - una vez suprimida toda muerte y toda enfermedad-, la vida sin mezcla venga a quedarse en todos aquellos que fueron capaces de recibir en ellos al Logos como Dios".

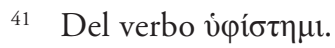


nados como "hombres de Dios»-, lo mismo en sentido más general, todo hombre puede ser enviado de Dios, pero en sentido propio ningún otro es llamado «enviado de Dios", si no es el que ha venido a esta vida al servicio de Dios y en el cumplimiento de la salvación de la raza de los hombres. Nosotros no hemos entonces encontrado alusión a un envío hecho por Dios para nadie más que los santos: para Isaías, como lo hemos recordado antes; para Jeremías: «Tú irás hacia todos aquellos a los que yo te enviaré»; para Ezequiel: «Mira que yo te envío hacia pueblos de hostiles que se han rebelado contra mí». A riesgo de parecer fuera de tema citar estos ejemplos de envío en la vida a propósito del objeto de nuestra investigación, pues ellos no llaman «envío» el hecho de ser enviado pura y simplemente en esta vida de un lugar exterior a esta vida, sin embargo incluso en estas condiciones, no será absurdo adoptar el razonamiento a nuestro problema haciendo esta observación: si, según nuestras citas, solo son los santos los que Dios dice enviar, sin embargo es necesario igualmente admitirlo para todos los que son enviados en esta vida ${ }^{42}$.

Este fragmento evidencia entonces que en el estudio escriturístico que hace el maestro alejandrino, si bien todas las almas han sido enviadas por Dios, solo las de los seres puros o santos tienen una preexistencia que puede ser denominada "ministerial": esto es con una razón claramente explícita. Tal sería entonces la misión de Juan: anunciar y dar testimonio de la venida de Jesús Cristo.

A continuación Orígenes explicita su posición con respecto a Juan: es un ángel que ha sido enviado por Dios. El maestro alejandrino fundamenta su teoría de la posibilidad de que un ángel pueda convertirse, la encuentra en el apócrifo judío "La plegaria de José ${ }^{43}$ ”. Los dos fragmentos que Orígenes cita son los únicos conocidos por la posteridad ${ }^{44}$. El que utiliza en este análisis resulta sumamente interesante porque explícitamente le confiere autoridad a un apócrifo para dilucidar una cuestión tan compleja como la posibilidad de transformación de ángel a hombre. El segundo también forma parte del texto del Comentario al Evangelio de

42 In Joh. Com., II, 183-185.

43 H. Pietras, "L'apocrifo "Preghiera di Giuseppe" nell' interpretazione origeniana-Clo II.31.188-190" en Origeniana Decima. Origen as writer (Louvain, 2011) 545-559.

44 Cf. J. Danielou, Teología del Judeocristianismo (Madrid, 1958) 41. 
Juan y si bien no lo denomina apócrifo es una declaración sobre lo que ha leído en las "tablillas del cielo" ${ }^{45}$. Veamos entonces los fragmentos:

"Ya que nosotros estamos hablando simplemente de Juan y estudiando su envío, no será inoportuno indicar la conjetura que nos hemos formado sobre el tema. Leyendo la profecía que le concierne: «Mira que yo envío mi ángel delante ti (rostro), para preparar tu camino", nosotros nos preguntamos si no es uno de los santos ángeles afectados al servicio de Dios que ha sido enviado como precursor de nuestro Salvador. Si el primer nacido de toda criatura se ha encarnado por amor hacia los hombres, no hay nada de extraño en que haya habido émulos e imitadores del Cristo, que han puesto su satisfacción en servir su bondad hacia los hombres en un cuerpo semejante al suyo. ¿Quién no se sorprenderá con el hecho de que Juan tiemble de alegría en el seno de su madre, mostrándose de esta manera superior a la naturaleza común de los hombres?

Si entre los apócrifos en uso entre los judíos, se admite el que está titulado «La plegaria de Josefo» se encontrará allí, expuesta abierta y claramente, la doctrina según la cual aquellos que comparados a los(otros) hombres gozan de entrada de cualidades excepcionales y que son por mucho superiores a las otras almas, se rebajaron de la condición de ángeles hasta la naturaleza humana”.

Es importante destacar nuevamente que la prueba teológica que le permite fundamentar su teoría acerca de la posibilidad de que ángel pueda convertirse en hombre, la encuentra en un apócrifo judío. Este fragmento entonces, nos permite una primera conclusión parcial: la preexistencia es un supuesto esencial del origenismo, según el cual la distinción entre ángeles, hombres y demonios no implica un orden entitativo irreductible y cerrado, sino que a través del progreso espiritual puede ser modificable. Tal como lo afirmó H. Jonas, el alma ( $\psi v \chi \eta ́ v)$ para Orígenes, más que una substancia simple es un estado espiritual complejo que debe progresar y evolucionar hasta recobrar su calidad de voé $\varsigma_{-} v_{0}{ }^{46}$. Esto, Orígenes, ya lo había afirmado claramente en el capítulo XXIII del Libro II al mostrar que :

45 Cf. In Joh. Com., I, 68. Está idea reaparecerá más adelante (I, 221) y en otro escrito de la misma época, el Comentario sobre el Génesis: "El cielo entero es semejante a un libro profético encerrando el futuro... Los signos celestes revelan la potencia de Dios, pues todos los acontecimientos del origen del mundo y su consumación, están impresos en un libro digno de Dios, el cielo".

46 H. Jonas, Gnosis und spatantiker Geist (Gottingen, 1993) 317. 
"Los términos ángel y hombre designan el mismo objeto

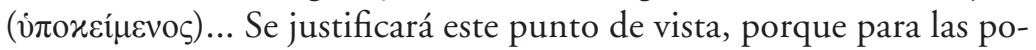
tencias superiores, los nombres no solo son nombres de naturaleza de los vivientes, sino funciones ( $\tau \dot{\alpha} \xi \varepsilon \omega v)$ donde tal o cual naturaleza dotada de razón ha sido investida por Dios” ${ }^{\prime 2}$.

Y finalizando el párrafo de una manera brillante, Orígenes busca una explicación al problema de la desigualdad de las condiciones al nacer de los seres humanos y de la aparente injusticia de Dios en el episodio de Jacob y de Esaú:

"Y sin duda Jacob, habiendo verdaderamente tenido estas palabras que están consignadas por este motivo, el texto «El ha suplantado a su hermano desde el seno de su madre ${ }^{48}$ ", deviene comprensible. Mira si el famoso problema del tema de Jacob y de Esaú no encuentra su solución: en efecto "cuando ellos no habían aun nacido y no habían hecho ni bien ni mal, a fin de que la libertad de elección divina fuera establecida - pues depende no de las obras sino del que llama-, se dijo: El mayor servirá al más joven, según lo que está escrito: Yo he amado a Jacob y yo he odiado a Esaú. ¿Qué decir entonces? ¿Y habría alguna injusticia en Dios? Lejos de esto». Si nosotros no recu-

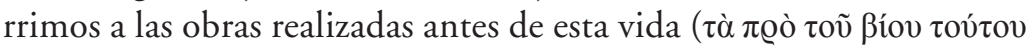

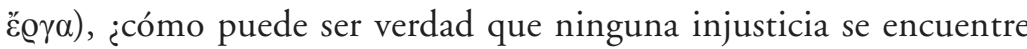
en Dios, cuando el mayor es sometido al más joven y odiado antes de haber cumplido los actos mereciendo la sujeción o mereciendo el odio? Nosotros hemos hecho una larga digresión citando el relato concerniente a Jacob y tomando como testimonio un escrito que no es indigno de consideración a fin de hacer más verosímil nuestra afirmación sobre Juan que lo representa, de acuerdo a la voz de la que habla Isaías, como un ángel venido en un cuerpo para dar testimonio a la luz" ${ }^{\prime 2}$.

Es importante mencionar que en este fragmento, C. Blanc traduce $\lambda$ óyos como hipótesis, pero con su acostumbrada seriedad, aclara a pie de página que este término puede tener dos sentidos diferentes: "texto o relato" e "hipótesis". Nosotros insistimos en que Orígenes considera a la preexistencia como una certeza que está presente en todo el texto bíblico y por eso hemos traducido este término como "afirmación".

47 In Joh. Com., II, 140.

48 Os 12, 3.

49 In Joh. Com., II, 191-192. 
Luego del análisis de este fragmento en donde explícitamente Orígenes afirma la preexistencia, quisiéramos hacer algunas comparaciones con el De Principiis. Comenzaremos diciendo que el tema de Esaú y Jacob es tratado por Orígenes en numerosas secciones de esta obra y siempre en relación a las causas precedentes a esta vida. Evidentemente es un tema que apasiona al alejandrino, al que dedica numerosas páginas. Sin embargo y por una cuestión de tiempo, solo citaremos un extenso fragmento, en donde será posible advertir las coincidencias con el contenido del Comentario al Evangelio de Juan:

"Pues bien, tal como, una vez escudriñadas las escrituras acerca de Esaú y Jacob de modo muy diligente, se descubre que no hay injusticia en Dios, aunque antes que hubiesen nacido y hecho algo -se entiende, en esta vida-, se haya dicho: «El mayor servirá al menor», y dado que se descubre que no es una injusticia el hecho que, aún en el vientre Jacob suplantó a su hermano, si pensamos que por los méritos de la vida precedente él fue legítimamente amado por Dios, como también mereció ser preferido a su hermano; de la misma manera, respecto a las criaturas celestiales, si advertimos que esta diversidad no es el principio de la creación, sino que por causas precedentes (sed ex praecedentibus causis pro meriti dignitate) de acuerdo a la dignidad del mérito, fue dispuesta por Dios una diversa función de servicio para cada uno; por ello cada uno, creado por Dios como nous o espíritu racional, de acuerdo a los impulsos del nous y los sentimientos de los ánimos, procuró para sí mismo mayor o menor mérito, y se volvió amable para Dios, o también digno de odio. En todo caso, como algunos de ellos, de mayores méritos, son mandados a padecer junto con los demás para mejorar el estado del mundo y ofrecer un servicio a los inferiores, por esto, ellos mismos participan de la paciencia del Creador, de acuerdo a lo que el mismo apóstol dice: «la creación quedó sometida a la vanidad, no queriendo, sino por Aquel que la sometió, en la esperanza»".

"Observando esta sentencia que declaró el apóstol cuando disertaba acerca del nacimiento de Esaú y Jacob: «Acaso hay injusticia en Dios? ¡De ninguna manera!, considero que esta misma sentencia también debe ser aplicada directamente a todas las criaturas, porque, tal como dijimos anteriormente, la justicia del Creador debe resplandecer en todas. Ella, según mi parecer, se mostrará tanto más claramente, si se sostiene que cada uno de los seres celestiales, terrenales o abismales poseen en sí mismos, antes del nacimiento corporal, las causas de la diversidad. Todo fue creado por el Logos y la Sabiduría de Dios y ha 
sido ordenado por su Justicia. Por la gracia de su misericordia provee a todos y recomienda a todos cada uno de los remedios con que pueden ser curados, y llama a la salvación»" 50 .

Las coincidencias de este bello texto del De Principiis con el Comentario son por demás evidentes, sin embargo hay tres aspectos en los que difieren y que es necesario mencionar. En los dos primeros libros

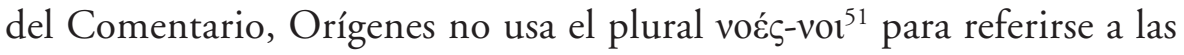
criaturas de la preexistencia y a su correspondiente doctrina del enfriamiento, sino que al referirse explícitamente a la caída de las mismas, llama seres puros o santos a los que llevaban en la beatitud una vida

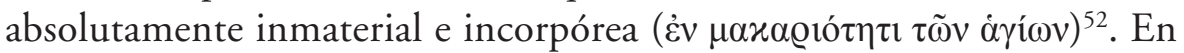
esto coincide totalmente con lo expresado en I, 6, $2^{53}$. En cuanto a su doctrina de los cuerpos etéreos de la preexistencia o de los cuerpos esplendorosos $(\alpha \hat{\gamma} \gamma o \varepsilon 1 \delta \varepsilon \varsigma \zeta)^{54}$, no hace en los primeros libros del Comentario un desarrollo exhaustivo. Solo se refiere una vez a los cuerpos eté-

50 Princ., II, 9, 7 (traducción de S. Fernández).

51 Cf. H. Crouzel, Orígenes. Un teólogo controvertido, 289. Al respecto el especialista francés realiza una interesante acotación: "Nunca hemos encontrado en las obras griegas de Orígenes el término voũ sen plural. Como él declina este término según la declinación ática y no la de la koiné, salvo cuando cita el Nuevo Testamento, habría dicho ciertamente en plural, vor y nunca voéc”.

52 Cf. In Joh. Com., I, XXVII, 96-97 "Algunos supondrán posiblemente que, entre todos los seres creados en el origen del mundo, lo que ha sido hecho 'al comienzo', son 'el cielo y la tierra'. Pero es mejor decir, de acuerdo a nuestra segunda cita, que de los numerosos seres creados con un cuerpo, el primero de los que tuvieron un cuerpo fue aquel que se llama el dragón designado en alguna parte como el 'enorme monstruo' y que el Señor ha domado 22. Es necesario preguntarse si mientras que los santos llevaban en la beatitud una vida absolutamente inmaterial e incorpórea, el que recibe el nombre de dragón no merece ser el primero en estar vinculado a la materia y a un cuerpo porque él cayó y se desvío de la vida perfecta; es por eso que el Señor, hablando del centro de la tempestad y de las nubes dice: 'El es el comienzo de la creación del Señor, hecha para ser la burla de sus ángeles’. Cf. Princ., I, 5.

53 Princ., I, 6, 2: "Aquellos, en cambio, que efectivamente se apartaron del estado de la primera bienaventuranza, pero no de modo irremediable, son sometidos a las antas y beatas órdenes que acabamos de describir, para ser conducidos y regidos; para que sirviéndose de su ayuda y reformados por la enseñanzas y por los castigos saludables, puedan volver y ser restituídos al estado de su bienaventuranza”.

54 Para comprender cabalmente esta tradición consultar el excelente libro, El Cuerpo Astral de F. García Bazán (Barcelona, 1993). Allí se examina el desarrollo que esta cuestión ha tenido desde Platón y Aristóteles, pasando por la filosofía caldaica, las enseñanzas neoplatónicas y la tradición cristiana. 
reos de los astros, en referencia a la doctrina del combate espiritual ${ }^{55}$. Sin embargo esta doctrina, que según nuestra opinión también debe ser considerada un postulado de su sistema se encuentra en el texto griego del Contra Celso ${ }^{56}$, lo cual muestra a las claras que es parte esencial de su pensamiento ${ }^{57}$.

Hay además dos temas muy delicados que se derivan de la cuestión de la preexistencia y que es imprescindible señalar. La primera se refiere a la cantidad de tiempo en el progreso espiritual ${ }^{58}$, que las criaturas espirituales necesitarán para recuperar su identidad divina. La segunda al cuándo y dónde cometieron las faltas que las alejaron transitoriamente del amor divino. Argumentar, como han hecho algunos especialistas contemporáneos que estas faltas fueron cometidas en la preexistencia, no arroja luz al problema ${ }^{59}$. No hay dudas en que Orígenes rechaza absolutamente la tradición griega de la $\mu \varepsilon \tau \varepsilon v \sigma \omega \mu \alpha ́ \tau \omega \sigma ı \varsigma$. Esto sí lo dice explícitamente en el Libro VI del Comentario al Evangelio de Juan ${ }^{60}$ y

55 In Joh. Com., I, XXVI, 173: "Algunos piensan que los hombres que han sido auténticamente enseñados por Jesús son superiores a las otras criaturas, que ellos sean tales, según unos, por naturaleza o, según otros de acuerdo a su línea de conducta caracterizada por un combate muy duro: Más numerosas son en efecto las penas y más peligrosa (o arriesgada) la existencia de los que están en la carne y la sangre que la de aquellos que están en cuerpos etéreos, pues si ellos asumieran cuerpos terrestres, incluso las luminarias del cielo no atravesarían por esta vida sin peligro ni sin ningún pecado. Pero para los que progresan, marchan a grandes pasos hacia la sabiduría y son juzgados dignos de ella, él no permanece señor-porque el servidor

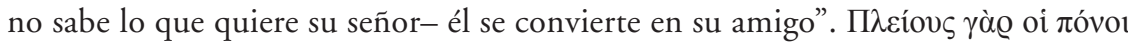

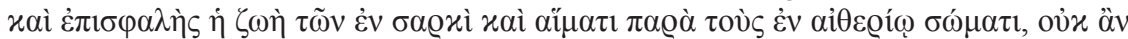

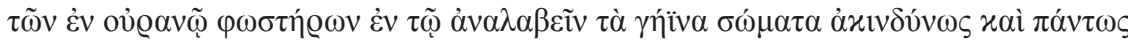

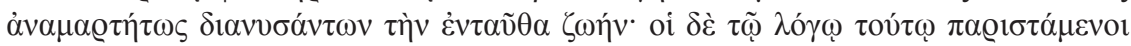

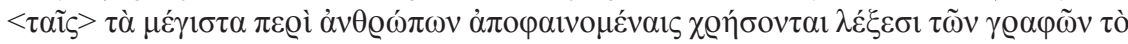

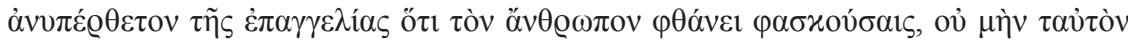

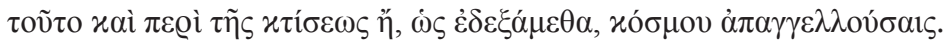

56 CCels II, 59

57 Cf. P. Ciner, "Cuerpo Etéreo de la Preexistencia y Cuerpo de Resurrección: historia del ocultamiento de una tradición”, en Epimeleia 36/37 (2011).

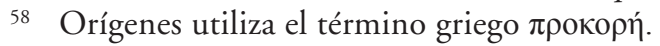

59 Cf. M. Maritano, "Metensomatosis", en Orígenes. Diccionario, 564-567.

${ }^{60}$ En el libro VI (cap. X a XIV) Orígenes estudiará largamente la posibilidad de que Juan Bautista fuera la reencarnación de Elías. En esta ocasión llegará a la conclusión de que la persona del profeta difiere de la del Bautista, si bien aclarará que ellos

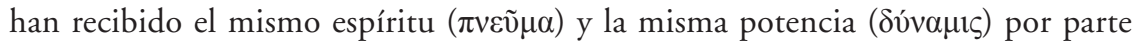
de Dios. Cf. M. Maritano, "L’argomentazione scritturística di origene contro i sostenitori della metensomatosi” en Origeniana Sexta (Louvain, 1995) 251-276. 
en el libro VII del Contra Celso ${ }^{61}$. Sin embargo su posición está absolutamente en las antípodas de cualquier teoría hilemórfica referida a una unión substancial de alma y del cuerpo. Ante este complejo problema y aquí sí a modo de hipótesis, podríamos argumentar que si se relacionara directamente la doctrina de los mundos sucesivos que Orígenes explicita en el De principiis ${ }^{62}$ y que también menciona claramente en una ocasión en el Comentario al Evangelio de Juan ${ }^{63}$ con la cuestión del progreso espiritual, se podría encontrar una solución aproximada. Decimos aproximada, porque carecemos de los textos que podrían probarla, por ejemplo el Comentario al Génesis. En efecto, si seguimos el razonamiento de la existencia de los mundos sucesivos no idénticos ${ }^{64}$, se podría pensar en la incorporación de una misma sustancia espiritual en cuerpos hu-

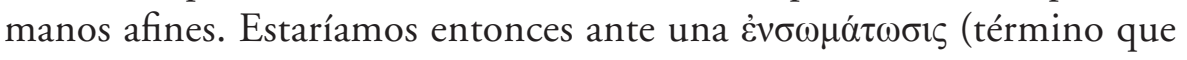
por otra parte utiliza para referirse a la incorporación del alma de Juan el Bautista ${ }^{65}$ ) y en ese caso, la distinción doncellas-esposas del Comentario

${ }^{61}$ CCels VII, 32.

62 Princ., II, 1, 3 "Puesto que el contenido de la discusión anterior ya mostró que los diversos impulsos y las variadas decisiones de las criaturas racionales han dado origen a la diversidad de este mundo, se debe ver si acaso no sea conveniente para este mundo, un desenlace también semejante al inicio. No hay duda de que su fin se hallará todavía entre mucha diversidad y variedad; esta variedad, alcanzada al final de este mundo, proporcionará nuevamente las causas y las ocasiones de las diversidades del otro mundo futuro, posterior a este, porque ciertamente el final de este mundo es inicio del [mundo] futuro" (trad. de Samuel Fernández).

63 In Joh. Com., I, XXVI, 177: "Pero aquel que no osa conceder al hombre tales privilegios, dirá afrontando este problema, que la creación sometida a la vanidad está afligida y gime más que aquellos que están en esta tienda, ya que permanece al servicio de la vanidad un tiempo más largo donde el combate del hombre

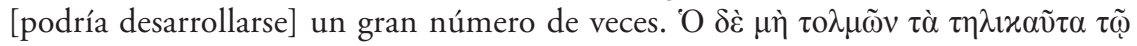

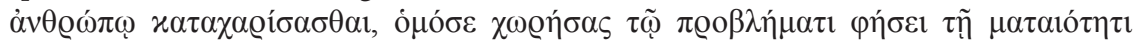

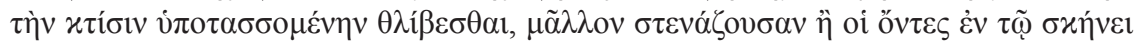

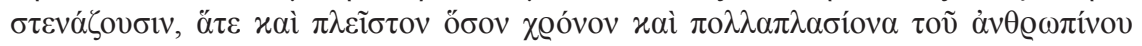

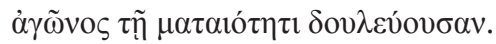

Princ., II, 3, 4.

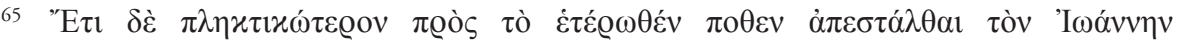

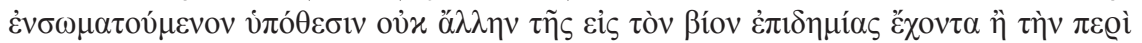
$\tau$ นิ๊

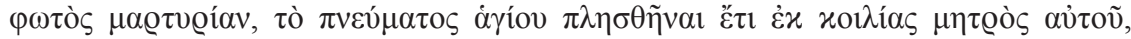

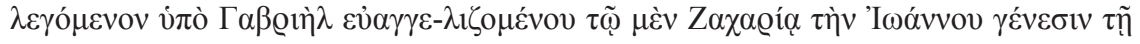

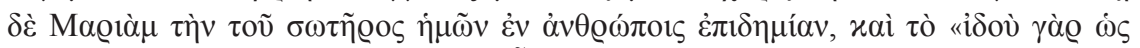

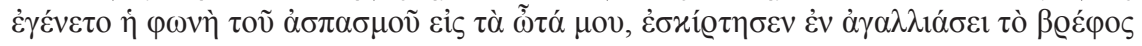

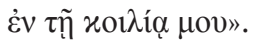


al Cantar de los Cantares $^{66}$ no sería una simple metáfora, sino una forma de comprender el progreso espiritual a través de diversas encarnaciones y a lo largo de estos mundos sucesivos. Desde esta perspectiva también cobraría total sentido, un texto "problemático" del De Principiis. Nos referimos a un fragmento de III, 1 conservado solo en latín donde se afirma que:

"A partir de esto, suponemos que, tal como frecuentemente hemos dicho, el alma es eterna e inmortal, por ello en muchos e ilimitados espacios, por inmensos e diversos siglos, es posible que descienda desde el más excelso bien hasta los más bajos males, y que sea restaurada desde los últimos males hasta el bien más excelso".

Sin embargo, salvo que se descubrieran nuevos textos (lo cual ya sabemos que no es imposible), por el momento sobre esto no se puede dar una opinión definitiva. Finalmente quisiéramos decir solo unas palabras con respecto a la fiabilidad o no de la traducción que Rufino ha realizado de los fragmentos referidos a la preexistencia. Al respecto pensamos que puede ser considerada bastante fiel y literal, ya que aún en textos que claramente son controvertidos desde una ortodoxia posterior a Orígenes, puede encontrarse el estilo y la presencia del maestro alejandrino. Esta evaluación estaría en consonancia con la posición de la prestigiosa especialista Emanuella Prinzivalli, quien comparó el texto griego del Codex Monacensis Graecus 314 con la traducción rufiniana que se conocía de estos salmos, en el reciente Colloquium Origenianum Undecimun realizado hace solo unos pocos días en Dinamarca ${ }^{67}$.

\section{CONClusiones}

El análisis de estos hermosos textos de Orígenes, nos ha permitido evidenciar que la preexistencia más que una hipótesis, es una certeza que se aplica universalmente a todas las criaturas espirituales. En el marco de esta universalidad de la preexistencia, se ha mostrado también con mucha claridad que la noción de pureza o santidad se define y limita por la ausencia de pecado en la misma preexistencia y esto es solo aplicable

${ }_{66}$ Cf. las siguientes traducciones: Sources Chrétiennes; Commentaire sur le Cantique (L. Brésard - H. Crouzel, eds., 375 (1992) y 376(1992); Comentario al Cantar de los Cantares, Biblioteca Patrística, Madrid, 1986, Introducción y notas de M. Simonetti, traducción de Argimiro Velasco Delgado.

67 E. Prinzivalli, "A fresh look at Rufinus as Translator" (Aarhus, en prensa). 
al alma de Jesús o a ángeles convertidos en hombres con misiones ministeriales, como Juan Bautista. En el caso de Esaú, que puede ser considerado paradigmático de la condición humana, la intención de Orígenes, ha sido mostrar que la lógica de la justicia de $\operatorname{Dios}^{68}$, tal como lo afirma en el De Principiis, siempre está presente y que, también usando una expresión del De principiis, el cosmos es una gran escuela para almas ${ }^{69}$. Allí y a través del progreso espiritual, postulado también clave de ambos textos, las almas reencontrarán su esencia divina plenificada.

Nuestra intención en esta ponencia, también ha sido mostrar que las condenas a la doctrina de la preexistencia se hicieron desde un paradigma teológico y filosófico que impiden comprender la relación existente entre tiempo y eternidad, entre principio y fin, entre esclavitud y liberación espiritual. En última instancia Orígenes a través de su doctrina de la preexistencia, ha sido fiel a la tarea de todo buen maestro: dar a sus discípulos los instrumentos para alcanzar por ellos mismos la Sabiduría, premio espiritual que no está fuera de ellos, sino en su ser más íntimo.

68 Princ., II, 9, 4 "Luego, confiados no en nuestro ingenio, sino en el auxilio de la Sabiduría misma, que creó todo, y de su Justicia, que creemos que está presente en todas las criaturas, a pesar de que por ahora no somos capaces de realizar afirmaciones, confiados en su misericordia, intentaremos investigar y escudriñar de qué manera esta tan grande variedad y diversidad del mundo se vea totalmente fundada en la lógica de la justicia. Pero me refiero solo a la razón general, pues, buscar la [razón] específica de cada caso es propio de inexpertos, y pretender explicarlo es propio de dementes" (traducción de S. Fernández).

69 Princ., II, 11, 6: schola animarum. 
